\title{
Major Translation Methods Used in Legal Documents: Translation of a Marriage Contract from Arabic into English
}

\author{
Omar EL GHAZI \\ Department of English Studies, Faculty of Arts and Humanities Ben M'sik \\ Hassan II University of Casablanca, Morocco \\ Chakib BNINI \\ Department of English Studies, Faculty of Arts and Humanities Ben M'sik \\ Hassan II University of Casablanca, Morocco
}

\begin{abstract}
Throughout history, the use of translation methods has constituted a source of lots of debates; some scholars advocate literal translation, others advocate free translation. In legal translation which is a special and specialized area of translational activity (Cao, 2007), and where documents are characterized by brevity, economy, and neatness to prevent fraud, additions, omissions or alterations in the text (Crystal \& Davy, 1969), mistakes or mistranslations can lead to disastrous repercussions. The present study deals primarily with the methods that translators of legal texts follow and adopt when rendering a legal document. A concise account of translation theories that have been adopted and are still being applied to legal translation is offered to attempt to show the main views towards the application of such translation theories to legal translation. Major methods often used in the translation of legal documents are then presented, discussing their validity to legal translation. This presentation includes literal translation, free translation, the functional approach to translation, transliteration \& transcription, loan translation, adaptation, description by definitions, lexical expansion, and descriptive substitution. The empirical part of this study is concerned with the analysis of a marriage contract translated from Arabic into English in an attempt to shed some light on the major methods adopted by the translator of this document and the reason behind using such methods.
\end{abstract}

Key words: Legal system, legal translation, marriage contract, methods of translation, source text, target text

Cites as: EL GHAZI, O., \& BNINI, C. (2019). Major Translation Methods Used in Legal Documents: Translation of a Marriage Contract from Arabic into English. Arab World English Journal for Translation \& Literary Studies, 3 (2). 122-138 . DOI: http://dx.doi.org/10.24093/awejtls/vol3no2.11 